\title{
FIRST RECORD OF Trichogramma pratissolii IN Eucalyptus spp. PLANTATION IN THE STATE OF MINAS GERAIS - BRAZIL
}

\author{
Ulysses Rodrigues Vianna*, Dirceu Pratissoli**, José Cola Zanuncio***, Gilberto Santos Andrade****, \\ Ranyze Barbosa Querino***** \\ *Eng. Agrônomo, M.Sc., UFV - ulyssesvianna@insecta.ufv.br \\ **Eng. Agrônomo, Dr., Depto. de Fitotecnia, UFES - pratissoli@cca.ufes.br \\ ***Eng. Florestal, Ph.D., Depto. de Biologia Animal, UFV - zanuncio@ufv.br \\ ****Eng. Agrônomo, Mestrando em Entomologia Agrícola, UFRP - gilberto.br@click21.com.br \\ *****Eng. Agrônomo, Dr., UNIMONTES - ranyze.querino@unimontes.br \\ Recebido para publicação: 06/07/2006 - Aceito para publicação: 01/09/2006
}

\begin{abstract}
Cardboards with Anagasta kuehniella (Zeller) (Lepidoptera: Pyralidae) eggs were fastened to eucalyptus plants in the Municipality of Paraopeba, State of Minas Gerais, Brazil aiming to collect egg parasitoids that naturally occur in this area. All individuals of egg parasitoids collected were identified as Trichogramma pratissolii Querino and Zucchi (Hymenoptera: Trichogrammatidae) and it represents the first report of this species in the Minas Gerais State and also in Eucalyptus plantations in Brazil.

Keywords: Insecta; biological control; egg parasitoid; lepidoptera defoliator.
\end{abstract}

\section{Resumo}

Primeiro relato de Trichogramma pratissolii em plantios de Eucalyptus spp. no estado de Minas Gerais - Brasil. Cartelas contendo ovos de Anagasta kuehniella (Zeller) (Lepidoptera: Pyralidae) foram fixadas em plantas de eucalipto no município de Paraopeba, estado de Minas Gerais, Brasil, visando coletar parasitóides de ovos que ocorressem naturalmente nessa área. Todos os parasitóides de ovos coletados foram identificados como Trichogramma pratissolii Querino e Zucchi (Hymenoptera: Trichogrammatidae) e representam o primeiro relatório dessa espécie no estado de Minas Gerais e também em plantações de eucalipto no Brasil.

Palavras-chave: Insecta; controle biológico; parasitóides de ovos; lepidóptera desfolhador.

\section{INTRODUCTION}

Egg parasitoids of the family Trichogrammatidae are important for the biological control of insect pests and they present, about, 18 species in 23 countries. Many of these species are been reared and mass liberated against pests in many cultures such as sugar cane, apple, cotton, beet, vegetables, vineyards and forests (ABDELGADER; HASSAN, 2002).

The species of the genus Trichogramma (Hymenoptera: Trichogrammatidae) have high potential as natural enemies and they are very abundant in number if individuals and species. The reports of natural occurrence of Trichogramma in Brazil corresponds to $31.8 \%$ of the total registered in South America (PARRA et al., 2002) and the Trichogramma pretiosum Riley (Hymenoptera: Trichogrammatidae) is the most common species of this group (PRATISSOLI et al., 2004; 2005; MONTEIRO et al., 2004). However, the success of these parasitoids depends on basic studies about them including collection, identification of lineages and/or species and the evaluation of their efficiency in the field (PARRA et al., 2002).

Outbreaks of Lepidoptera defoliators are been reported in Eucalyptus spp. plantations with economic damage to these plants in Brazil (OLIVEIRA et al., 2000; 2003). The importance of biological control programs made necessary the use of surveys in eucalyptus plantations of the V \& M Forest Company in the Municipality of Paraopeba, Minas Gerais Sate, Brazil (19¹6’38'S and 44²3'54'W) aiming to identify the egg parasitoids that, naturally, occur in these areas. 
Cardboards with $4.0 \times 2.5 \mathrm{~cm}$ and a central area of $2.5 \mathrm{~cm}^{2}$ with Anagasta kuehniella (Zeller) (Lepidoptera: Pyralidae) eggs turned unfeasible by exposing them to a germicidal lamp during 50 minutes were fastened to eucalyptus plants. These cardboards were packed in screened bags to fix and protecting them. They were maintained in the field during three days and, afterwards, they were carried to the laboratory to observe if the parasitism occurred. The cardboards with parasitized eggs were individualized in glass tubes $(8.5 \times 2.5 \mathrm{~cm})$ closed with PVC plastic film until the emergency or not of Trichogramma adults.

The male specimens obtained from A. kuehniella eggs were separated and killed in alcohol 70\%. Some of them were sent to $\operatorname{Dr}^{\mathrm{a}}$. R. B. Querino for identification because this is based on the male genitalia. All individuals sent were identified as Trichogramma pratissolii Querino and Zucchi (Hymenoptera: Trichogrammatidae). This species had been described based on specimens collected in avocado plantations the Espirito Santo State, Brazil (QUERINO; ZUCCHI, 2003). This is the second report of T. pratissolii in Brazil and the first one in Eucalyptus plantations and in the Minas Gerais State. This shows the potential of this egg parasitoid for the biological control in Eucalyptus plantations and it indicates that $T$. pratissolii may be widespread in many cultures and regions in Brazil.

\section{ACKNOWLEDGEMENTS}

To the V \& M Forest Company for the collection of the egg parasitoid and to $\mathrm{Dr}^{\mathrm{a}}$. R. B. Querino for the identification of T. pratissolii. To the Brazilian agencies "Conselho Nacional de Desenvolvimento Científico e Tecnológico (CNPq)", "Coordenação de Aperfeiçoamento de Pessoal de Nível Superior (CAPES)" and "Fundação de Amparo à Pesquisa do Estado de Minas Gerais (FAPEMIG)".

\section{REFERENCES}

ABDELGARDER, H.; HASSAN, S. A. Side effects of plant products on Trichogramma cacoeciae Marchal (Hym. Trichogrammatidae). IOBC/WPRS Bulletin, Chania, n. 25, p. 63-70, 2002.

MONTEIRO, L. B.; SOUZA, A.; BELLI, E. L.; QUERINO, R. B.; ZUCCHI, R. A. Ocorrência de Trichogramma pretiosum Riley (Hymenoptera: Trichogrammatidae) em ovos de Bonagota cranaodes (Meyrick) (Lepidoptera: Tortricidae) em macieira. Revista Brasileira de Fruticultura, Cruz das Almas, n. 26, p. 171-172, 2004.

OLIVEIRA, H. N.; ZANUNCIO, J. C.; PRATISSOLI, D.; CRUZ, I. Parasitism rate and viability of Trichogramma maxacalii (Hym.: Trichogrammatidae) parasitoid of the Eucalyptus defoliator Euselasia apisaon (Lep.: Riodinidae), on eggs of Anagasta kuehniella (Lep.: Pyralidae). Forest Ecology and Management, Amsterdam, n. 130, p. 1-6, 2000.

OLIVEIRA, H. N.; ZANUNCIO, J. C.; PRATISSOLI, D.; PICANÇO, M. C. Biological characteristics of Trichogramma maxacalii (Hymenoptera: Trichogrammatidae) on eggs of Anagasta kuehniella (Lepidoptera: Pyralidae). Brazilian Journal of Biology, São Carlos, S.P., n. 63, p. 647-653, 2003.

PARRA, J. R. P.; BOTELHO, P. S. M.; CORRÊA-FERREIRA, B. S.; BENTO, J. M. S. Controle biológico uma visão inter e multidisciplinar. In: PARRA, J. R. P.; BOTELHO, P. S. M.; CORREAFERREIRA, B. S.; BENTO, J. M. S. (Eds.) Controle biológico no Brasil: parasitóides e predadores. São Paulo: Manole, 2002, p. 125-142.

PRATISSOLI, D.; ZANUNCIO, J. C.; VIANNA, U. R.; ANDRADE, J. S.; GUIMARÃES, E. M.; ESPÍNDULA, M. C. Fertility life table of Trichogramma pretiosum and Trichogramma acacioi on eggs of Anagasta kuehniella at different temperatures. Pesquisa Agropecuária Brasileira, Brasília, D.F., n. 39, p. 193-196, 2004.

PRATISSOLI, D.; ZANUNCIO, J. C.; VIANNA, U. R.; ANDRADE, J. S.; ZANOTTI, L. C. M.; SILVA, A. F. Biological characteristics of Trichogramma pretiosum and Trichogramma acacioi (Hym.: Trichogrammatidae), parasitoids of the avocado defoliator Nipteria panacea (Lep.: Geometridae), on eggs of Anagasta kuehniella (Lep.: Pyralidae). Brazilian Archives of Biology and Technology, Curitiba, n. 48, p. 7-13, 2005.

QUERINO, R. B.; ZUCCHI, R. A. New species of Trichogramma Westwood (Hymenoptera: Trichogrammatidae) associated with lepidopterous eggs in Brazil. Zootaxa, Auckland, n. 163, p. 1-10, 2003. 